CZASOPISMO INŻYNIERII LĄDOWEJ, ŚRODOWISKA I ARCHITEKTURY JOURNAL OF CIVIL ENGINEERING, ENVIRONMENT AND ARCHITECTURE

JCEEA, t. XXXIII, z. 63 (2/II/16), kwiecień-czerwiec 2016, s. 429-444

Agnieszka STEC ${ }^{1}$

\title{
MODEL KOSZTOWY RETENCYJNEGO ZBIORNIKA RUROWEGO
}

\begin{abstract}
W artykule przedstawiono zagadnienia związane $\mathrm{z}$ retencjonowaniem ścieków w zbiornikach rurowych oraz opisano sformułowany model kosztowy tego zbiornika, który w kolejnym etapie badań zostanie przekształcony w model optymalizacyjny i następnie zaimplementowany w języku programowania AMPL (A Mathematical Programming Language). Do budowy modelu kosztowego zbiornika rurowego zastosowano metodologię Life Cycle Cost, która umożliwia wyznaczenie kosztów w całym cyklu istnienia danego obiektu. W modelu tym wzięto pod uwagę początkowe nakłady inwestycyjne związane z budową zbiornika oraz koszty eksploatacyjne wynikającego z jego funkcjonowania w systemie kanalizacyjnym. Metodologia Life Cycle Cost umożliwia podjęcie właściwej, z punktu widzenia inwestora i eksploatatora, decyzji. W nakładach inwestycyjnych uwzględniono nakłady przeznaczone na zakup terenu pod realizację inwestycji, nakłady przeznaczone na realizację robót ziemnych związanych z budową zbiornika retencyjnego, nakłady obejmujące wykonanie rurowej konstrukcji zbiornika oraz nakłady przeznaczone na budowę sieci kanalizacyjnej zlokalizowanej poniżej zbiornika retencyjnego. W związku z tym, że jest to zbiornik grawitacyjny, który nie wymaga ponoszenia kosztów wynikających z pompowania ścieków, w corocznych kosztach eksploatacyjnych wzięto pod uwagę jedynie koszt czyszczenia zbiornika z osadów. Ze względu na to, iż systemy kanalizacyjne i obiekty z nimi współdziałające projektowane są na bardzo długi okres czasu, w opracowanym modelu kosztowym nie uwzględniono kosztów likwidacji zbiornika.
\end{abstract}

Słowa kluczowe: zbiorniki rurowe, kanalizacyjne zbiorniki retencyjne, Life Cycle Cost, optymalizacja

\section{Wprowadzenie}

Zgodnie z wytycznymi Ramowej Dyrektywy Wodnej Unii Europejskiej powinna być stosowana nowoczesna i racjonalna gospodarka wodno-ściekowa, która opiera się na filozofii rozwoju zrównoważonego [7]. W myśl tej idei podejmowane są działania zmierzające do ograniczenia wielkości spływów wód deszczowych poprzez zastosowanie w zlewniach różnych form retencji i infiltra-

\footnotetext{
${ }^{1}$ Agnieszka Stec, Politechnika Rzeszowska, Wydział Budownictwa, Inżynierii Środowiska i Architektury, 35-959 Rzeszów, al. Powstańców Warszawy 12, e-mail: stec_aga@prz.edu.pl, tel. 178651071
} 
cji wód do gruntu. W praktyce, w tym celu zastosowanie znajdują rowy i niecki chłonne, skrzynki i komory rozsączające, a przede wszystkim zbiorniki retencyjne i retencyjno-infiltracyjne [2, 9, 18, 24, 25].

Głównym zadaniem zbiorników retencyjnych jest regulowanie wielkości strumienia objętości ścieków przepływających przez system kanalizacyjny. Obiekty te pozwalają na przechwycenie i czasowe magazynowanie nadmiaru ścieków deszczowych lub ogólnospławnych, które następnie stopniowo odprowadzane są do odbiornika lub do sieci transportującej ścieki w kierunku oczyszczalni. Zbiorniki retencyjne przekształcają niekorzystny hydrogram przepływu o dużym natężeniu i krótkim czasie trwania na hydrogram spłaszczony o mniejszym natężeniu i dłuższym czasie trwania. Jest to korzystne z punktu widzenia działania sieci kanalizacyjnej i innych obiektów na niej zlokalizowanych. Zważywszy na coraz częstsze występowanie ekstremalnych zjawisk pogodowych, zwłaszcza intensywnych opadów deszczu, których skutkiem może być przeciążenie hydrauliczne systemu kanalizacyjnego [15], zagadnienie retencjonowania ścieków nabiera coraz większego znaczenia.

Zastosowanie znajdują zbiorniki o różnych układach hydraulicznych komór akumulacyjnych, głównie o działaniu grawitacyjnym i grawitacyjno-pompowym $[4,5,17]$. Tradycyjne rozwiązania to wielkogabarytowe konstrukcje żelbetowe, których lokalizacja w terenach zurbanizowanych może napotykać na trudności spowodowane brakiem wystarczającej powierzchni pod budowę zbiornika oraz gęstej struktury istniejących sieci podziemnych. W takich przypadkach korzystnym rozwiązaniem może być retencjonowanie ścieków w zbiornikach rurowych zbudowanych z odcinków rur o znacznych średnicach.

Zasadniczym problemem $\mathrm{w}$ projektowaniu zbiorników retencyjnych, na budowę których wydatkowane są znaczne środki finansowe jest wybór optymalnego rozwiązania układu hydraulicznego zbiornika. Wybór taki musi uwzględniać wiele kryteriów. Do najważniejszych z nich należą nakłady inwestycyjne, koszty eksploatacyjne, możliwości techniczne stosowania różnych rozwiązań zbiorników oraz hydrauliczne ich oddziaływanie na funkcjonowanie sieci i pozostałych obiektów z nią współdziałających.

Metodykę umożliwiającą dokonanie wyboru najkorzystniejszego rozwiązania zbiornika retencyjnego przedstawiono w pracy doktorskiej [22]. W ramach opisanych w niej badań sformułowano modele kosztowe i optymalizacyjne wybranych zbiorników grawitacyjnych i grawitacyjno-pompowych. W rozwiązaniu złożonego problemu decyzyjnego zastosowano metodę optymalizacji jednokryterialnej. Kryterium wyboru stanowiło minimum kosztów Life Cycle Cost ( $L C C$ ) budowy i eksploatacji zbiornika retencyjnego w systemie kanalizacyjnym w całym okresie funkcjonowania tego obiektu.

$\mathrm{W}$ artykule przedstawiono wyniki kontynuacji tych badań, które rozszerzono o model optymalizacyjny zbiornika rurowego. W celu stworzenia modelu optymalizacyjnego tego zbiornika konieczne było opracowanie w pierwszym etapie badań modelu kosztowego $L C C$, który opisano poniżej. 


\section{Charakterystyka zbiornika rurowego}

Idea budowy zbiorników retencyjnych w postaci odcinków kanałów o dużych średnicach powstała w Niemczech już w latach 30. XX wieku. Początkowo wykonywano je jako obiekty murowane, które wraz z rozwojem technicznym i technologicznym zastępowano prefabrykowanymi odcinkami rur kanalizacyjnych. Obecnie tego typu rozwiązania budowane są głównie z elementów wykonanych z tworzyw sztucznych, najczęściej z polietylenu i żywic poliestrowych.

Do wielu zalet kanalizacyjnych zbiorników rurowych można zaliczyć głównie:

- łatwy i szybki montaż konstrukcji zbiornika, nawet w warunkach zimowych,

- niewielki ciężar zbiornika w porównaniu do konstrukcji betonowych czy żelbetowych,

- długookresowa trwałość i odporność na procesy korozyjne,

- łatwy i sprawny transport gotowych zbiorników lub ich elementów, z których powstaną na placu budowy zbiorniki charakteryzujące się znacznymi pojemnościami,

- ograniczenie złożonych obliczeń wytrzymałościowych, które wymagane są przy podziemnych konstrukcjach zbiorników żelbetowych,

- uniwersalność zastosowań wynikająca z dostępności rur w szerokim zakresie średnic,

- możliwość posadowienia zbiornika w trudnych warunkach gruntowowodnych,

- możliwość usytuowania zbiornika w różnych wariantach inwestycyjnych względem sieci kanalizacyjnej, w tym również w pasie drogowym i pod parkingami.

Działanie typowego zbiornika rurowego oparte jest na modelu klasycznego zbiornika kanalizacyjnego typu SIMPLEX. W zależności od wymaganej pojemności retencyjnej zbiornika oraz dostępności powierzchni przeznaczonej pod jego budowę, tego typu rozwiązania mogą być lokalizowane w pojedynczych układach liniowych lub w konfiguracjach wykonanych z kilku kanałów połączonych równolegle. Przykład realizacji zbiornika w układzie równoległym pokazano na rysunku 1, natomiast na rysunku 2 przedstawiono rozwiązanie zbiornika rurowego w układzie liniowym [16].

Przykładem rozwiązania zbiornika rurowego może być patent $\mathrm{nr} 217405$ pt. Retencyjny kanat ściekowy [19]. Jest to konstrukcja charakteryzująca się tym, że przestrzeń wewnętrzna kanału została podzielona na oddzielne komory przegrodami usytuowanymi prostopadle do kierunku przepływu ścieków. Natomiast przegrody te posiadają $\mathrm{w}$ dolnej strefie otwory przepływowe, umożliwiające transport ścieków do kolejnych komór zbiornika. 


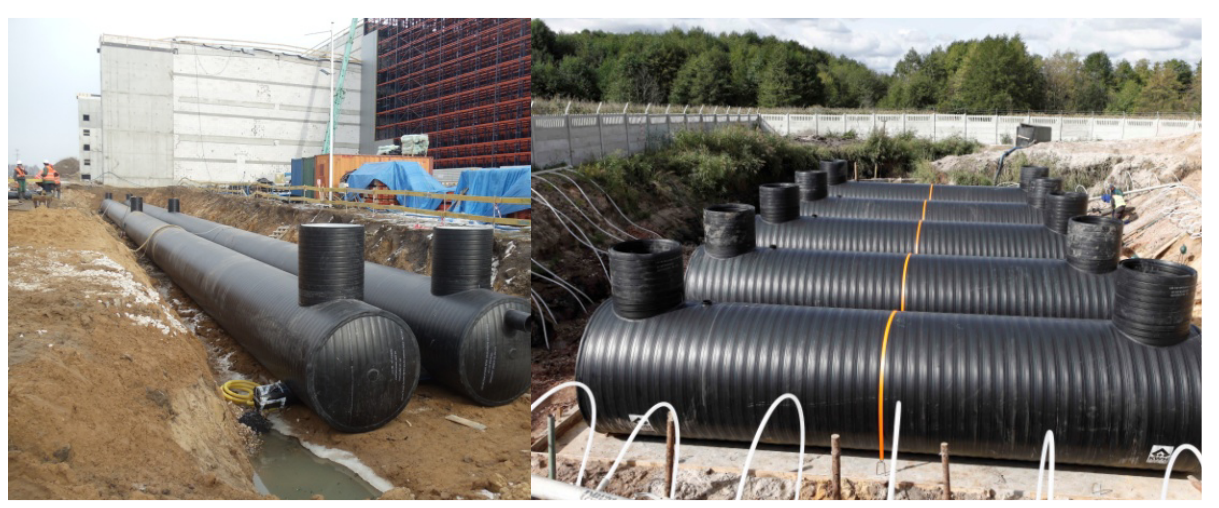

Rys. 1. Zbiorniki rurowe firmy Uponor Infra w układzie równoległym [16]

Fig. 1. The pipe tanks of Uponor Infra Company in parallel connection [16]

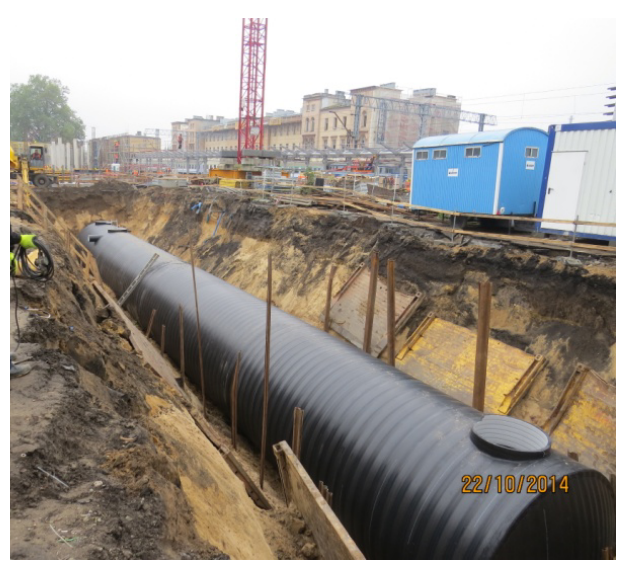

Rys. 2. Zbiornik rurowy firmy Uponor Infra w układzie liniowym [16]

Fig. 2. The pipe tank of Uponor Infra Company in linear connection[16]

Podobną konstrukcję stanowi wynalazek nr 216617 pt. Rurowy zbiornik retencyjny [6], w którym przestrzeń wewnętrzna podzielona jest również na sekcje nieruchomymi przegrodami, umieszczonymi w studzienkach lub komorach kanalizacyjnych. Przegrody te zamontowane są z zachowaniem pewnej odległości od dna kanału tak, aby tworzyły otwory przepływowe między kolejnymi sekcjami. W zależności od wymaganej, obliczeniowej pojemności zbiornika, posiada on odpowiednią liczbę sekcji o określonej średnicy i długości. Sposób funkcjonowania rurowego zbiornika retencyjnego, zgodnie $\mathrm{z}$ tym rozwiązaniem jest determinowany warunkami hydraulicznymi, jakie ustala się na odpływie ścieków ze zbiornika oraz na przegrodach zamontowanych na długości zbiornika. Na rysunku 3 przedstawiono przekrój zbiornika rurowego w ostatniej fazie jego napełniania. 


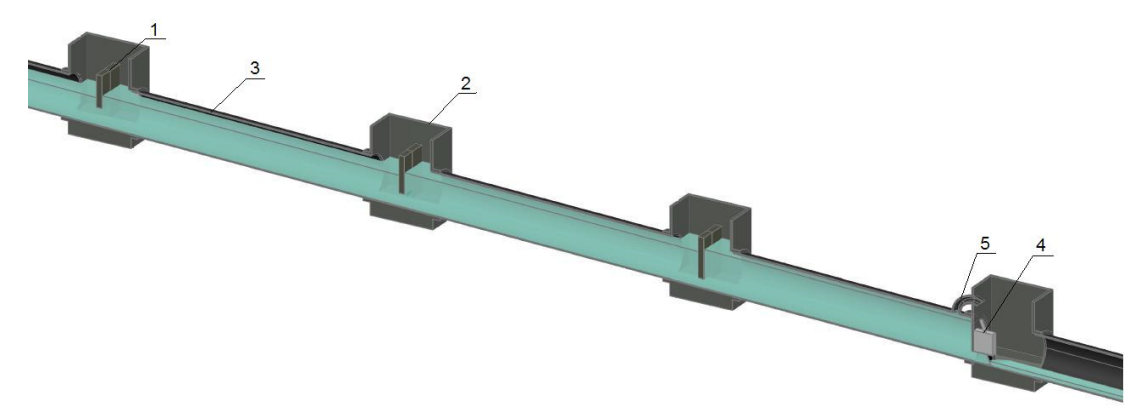

Rys. 3. Rurowy zbiornik retencyjny w ostatniej fazie jego napełniania: 1 - przegroda, 2 - komora, 3 - sekcja, 4 - regulator przepływu, 5 - przewód awaryjny

Fig. 3. Pipe tank in the final phase of its filling: 1 - partition, 2 - chamber, 3 - section 4 - flow regulator, 5 - emergency pipe

\section{Model kosztowy Life Cycle Cost}

Wybór optymalnego rozwiązania zbiornika retencyjnego zależy od wielu czynników. Do najważniejszych z nich należą warunki hydrauliczne sieci, na której ma być zlokalizowany zbiornik oraz lokalne uwarunkowania inwestycji, m.in. ukształtowanie terenu, poziom wód gruntowych oraz rodzaj gruntu i stopień intensyfikacji zabudowy infrastruktury podziemnej i naziemnej.

W pierwszym etapie projektowania zbiornika retencyjnego należy wyznaczyć jego pojemność, która wynika z lokalizacji, warunków hydraulicznych w sieci kanalizacyjnej przed i za zbiornikiem oraz parametrów charakteryzujących zlewnię. Następnie należy przyjąć kilka różnych wariantów inwestycyjnych zbiorników i dokonać analizy opłacalności ich zastosowania.

Do budowy modeli kosztowych poszczególnych rozwiązań wskazane jest zastosowanie metodologii Life Cycle Cost $(L C C)$, która umożliwia uwzględnienie wszystkich kosztów cyklu funkcjonowania obiektów budowlanych, tj. początkowych nakładów inwestycyjnych, kosztów eksploatacyjnych oraz kosztów związanych z ich likwidacją $[28,29]$. Stosowanie tej metody jest zalecane przez światowe instytucje finansowe, gdyż jej wyniki dostarczają cennych informacji i mogą wspomóc decydenta $w$ procesie podejmowania decyzji inwestycyjnych.

Idea metodologii Life Cycle Cost powstała w Stanach Zjednoczonych Ameryki w latach 60-tych XX wieku. Departament Obrony Stanów Zjednoczonych wprowadził ją do praktyki przy realizacji zamówień publicznych [8]. Obecnie analiza kosztów $L C C$ stosowana jest w różnych sektorach gospodarki, m.in. w energetyce, przemyśle, transporcie, budownictwie i infrastrukturze. Wykorzystywana jest głównie jako narzędzie w procesie podejmowania decyzji i zarządzania $[1,10]$.

W Polsce metoda obliczeń $L C C$ nie jest powszechnie stosowaną metodą oceny rozwiązań alternatywnych. W literaturze przedmiotu można znaleźć informacje o jej wykorzystaniu m.in. w transporcie kolejowym [27], budownic- 
twie [3, 13], technice pompowej [11, 13, 26] oraz w zagospodarowaniu wód opadowych [20, 21, 23].

$\mathrm{W}$ artykule przedstawiono etapy tworzenia modelu kosztowego zbiornika rurowego, który następnie posłuży do stworzenia modelu optymalizacyjnego tego zbiornika. Jako kryterium optymalizacji przyjęto minimum kosztów LCC budowy i funkcjonowania zbiornika retencyjnego.

Wartość kosztów $L C C$ w sposób ogólny można zapisać równaniem (1) $[28,29]$.

$$
L C C=I N V+O M C+D M C
$$

gdzie: $I N V$ - nakłady inwestycyjne, zł;

$O M C$ - koszty eksploatacyjne, zł;

$D M C$ - koszty likwidacji lub gospodarczego wykorzystania, zł.

W związku z tym, że systemy kanalizacyjne i obiekty retencyjne z nimi współdziałające projektowane są na okres 50 lat i więcej w modelu kosztowym zbiornika rurowego nie uwzględniono kosztów jego likwidacji $D M C$. Biorąc to pod uwagę całkowite koszty $L C C$ można wyznaczyć z zależności (2) [12].

$$
L C C=K_{I}+\sum_{t=1}^{T} K_{E}\left(\frac{1}{(1+r)^{t}}\right)
$$

gdzie: $K_{I}$ - całkowite nakłady inwestycyjne budowy rurowego zbiornika retencyjnego, zł;

$K_{E}$ - roczne koszty eksploatacyjne wynikające z funkcjonowania rurowego zbiornika retencyjnego, zł;

$T$ - okres eksploatacji zbiornika retencyjnego, lata;

$t$ - kolejny rok eksploatacji zbiornika, -;

$r$-stopa dyskontowa, -.

W całkowitych nakładach inwestycyjnych $K_{I}$ uwzględniono nakłady przeznaczone na zakup terenu pod realizację inwestycji, nakłady związane z realizacją robót ziemnych, nakłady przeznaczone na wykonanie rurowej konstrukcji zbiornika retencyjnego i nakłady inwestycyjne potrzebne na wykonanie sieci kanalizacyjnej zlokalizowanej poniżej zbiornika. Całkowite nakłady inwestycyjne $K_{I}$ można zatem opisać wzorem (3).

$$
K_{I}=K_{z i e m}+K_{r z}+K_{k}+K_{s}
$$

gdzie: $K_{z i e m}$-nakłady inwestycyjne przeznaczone na zakup terenu pod realizację inwestycji, zł;

$K_{r z}$ - nakłady inwestycyjne przeznaczone na realizację robót ziemnych związanych z budową zbiornika retencyjnego, zł; 
$K_{k}$ - nakłady inwestycyjne przeznaczone na wykonanie rurowej konstrukcji zbiornika retencyjnego, zł;

$K_{\text {sieci }}$ - nakłady inwestycyjne przeznaczone na budowę sieci kanalizacyjnej zlokalizowanej poniżej zbiornika retencyjnego, zł.

Z kolei w rocznych kosztach eksploatacyjnych $K_{E}$ uwzględniono koszty czyszczenia komór z osadów ściekowych i koszt obsługi. W ujęciu całościowym koszty te opisano zależnością (4).

$$
K_{E}=K_{c z}+K_{o b}
$$

gdzie: $K_{c z}-$ koszt czyszczenia komór zbiornika retencyjnego, zł;

$K_{o b}-$ koszt obsługi, zł.

Istotnym zagadnieniem $\mathrm{w}$ tworzeniu modelu kosztowego zbiornika rurowego jest wyznaczenie charakterystycznych parametrów projektowych, które będą mieć decydujący wpływ na wartość kosztów $L C C$ zbiornika. Na rysunku 4 przedstawiono przekrój analizowanego zbiornika wraz z zaznaczonymi parametrami projektowymi.

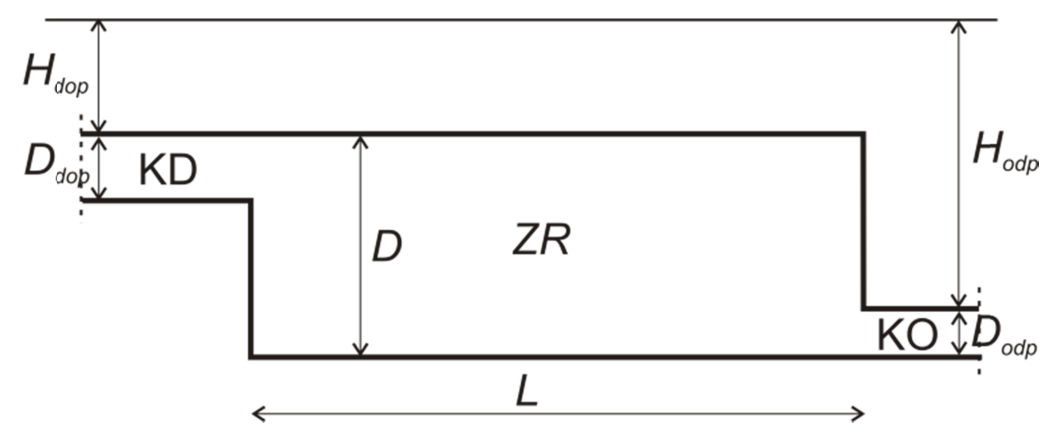

Rys. 4. Charakterystyczne parametry projektowe rurowego zbiornika retencyjnego: $\mathrm{KD}$ - kanał dopływowy, $\mathrm{KO}$ - kanał odpływowy, ZR - zbiornik rurowy, $H_{d o p}$ - zagłębienie kanału dopływowe:go do zbiornika, $H_{o d p}$ - zagłębienie kanału odpływowego ze zbiornika, $D_{d o p}$ - średnica kanału dopływowego, $D_{o d p}$ - średnica kanału odpływowego, $D$-średnica zbiornika rurowego, $L$ - długość zbiornika rurowego

Fig. 4. The characteristic design parameters of the pipe retention tank: KD - inlet channell, KO - drainage channel, ZR - pipe tank, $H_{d o p}$ - level of the inlet channel to the tank, $H_{o d p}$ - level of the reservoir drainage channiel, $D_{d o p}$ - diameter of the inlet channel, $D_{\text {odp }}$ - diameter drainage channel, $D$ - diameter of the pipe tank, $L$ - length of the pipe tank

Nakłady inwestycyjne obejmujące zakup ziemi pod realizację inwestycji $K_{z i e m}$ uzależnione są od powierzchni zbiornika w rzucie poziomym oraz jednostkowej ceny zakupu terenu. W modelu kosztowym powierzchnia działki, która musi zostać zakupiona została zwiększona o pas terenu o szerokości $s$ wokół zbiornika, wynikający z uwarunkowań technicznych prowadzenia budowy, m.in. możliwości wykonania wykopów ziemnych przy jego realizacji. Nakłady te określono wzorem (5). 


$$
K_{\text {ziem }}=C_{z i e m} \cdot(L+2 s) \cdot(D+2 d)
$$

gdzie: $C_{z i e m}$ - cena jednostkowa zakupu terenu pod realizację inwestycji, $\mathrm{z} \mathrm{z} / \mathrm{m}^{2}$;

$L$ - długość zbiornika rurowego, $\mathrm{m}$;

$D$ - średnica zbiornika rurowego, $\mathrm{m}$;

$s$ - szerokość pasa terenu wokół zbiornika retencyjnego wynikający $\mathrm{z}$ uwarunkowań technicznych wykonywania jego konstrukcji, m.

W początkowych nakładach inwestycyjnych należy uwzględnić również koszty wydobycia gruntu i jego wywozu, zabezpieczenia skarp wykopów oraz ich odwodnienia. Wartość tej składowej nakładów może się znacznie różnić nawet $w$ ramach tej samej inwestycji, gdyż w dużym stopniu uzależniona jest ona od warunków gruntowo-wodnych, głębokości posadowienia zbiornika i wybranej techniki realizacji robót. Wartość nakładów $K_{r z}$ wzrasta wraz z głębokością wykopu i poziomem nawodnienia gruntu. W opracowanym modelu kosztowym ceny jednostkowe poszczególnych robót budowlanych uwzględniają koszty pracy sprzętu budowlanego oraz ludzi. Nakłady inwestycyjne $K_{r z}$, które konieczne są do poniesienia przy realizacji robót ziemnych zapisano $\mathrm{w}$ postaci zależności (6).

$$
K_{r z}=K_{o d w}+K_{w b}+K_{w y}+K_{w d}+K_{p i a s}+K_{z a s}
$$

gdzie: $K_{o d w}$ - nakłady inwestycyjne związane z odwodnieniem wykopów, zł;

$K_{w b}$ - nakłady inwestycyjne przeznaczone na wbijanie ścianek szczelnych, zł;

$K_{w y}$ - nakłady inwestycyjne przeznaczone na wyciąganie ścianek szczelnych, zł;

$K_{w d}$ - nakłady inwestycyjne przeznaczone na wydobycie i wywóz gruntu, $\mathrm{zł}$

$K_{\text {pias }}$ - nakłady inwestycyjne przeznaczone na wykonanie podsypki piaskowej pod dnem zbiornika retencyjnego, zł;

$K_{z a s}$ - nakłady inwestycyjne przeznaczone na zasypania wykopów i obsypanie zbiornika po wykonaniu jego konstrukcji, zł.

Nakłady inwestycyjne związane z odwodnieniem wykopów $K_{o d w}$ uzależnione są od poziomu wody gruntowej, techniki prowadzenia robót oraz czasu realizacji inwestycji. Nakład ten dla zbiornika rurowego zapisano formułą (7).

$$
K_{o d w}=C_{o d w} \cdot I_{g o d z}
$$

gdzie: $C_{o d w}$ - cena jednostkowa odpompowywania wody gruntowej z wykopu, zł/godz.;

$I_{\text {godz }}$ - liczba godzin pompowania wody gruntowej z wykopu, godz. 
Planując prace ziemne należy również przewidzieć zabezpieczenie wykopów przed obsunięciem się gruntu. Najczęściej realizowane jest to przez zastosowanie ścianek szczelnych wykonanych z podłużnych elementów stalowych lub z tworzyw sztucznych. Zazwyczaj zabijane są one czasowo na okres prowadzenia robót, a po ich zakończeniu ścianki te zostają usunięte. W związku z tym w modelu kosztowym uwzględniono nakłady $K_{w b}$ i $K_{w y}$, które zależą głównie od głębokości i wymiarów wykopów. Jednostkowa cena wbicia i usunięcia ścianek szczelnych $C_{w b}$ i $C_{w y}$ została ustalona za metr bieżący obwodu wykopu i każdy metr jego głębokości. Formułując model zbiornika rurowego, nakłady te zostały odpowiednio określone z zależności (8) i (9).

$$
\begin{aligned}
& K_{w b}=C_{w b} \cdot[2(D+2 s)+2(L+2 s)] \cdot\left(H_{o d p}+D_{o d p}+G_{p i a s}+a\right) \\
& K_{w y}=C_{w y} \cdot[2(D+2 s)+2(L+2 s)] \cdot\left(H_{o d p}+D_{o d p}+G_{p i a s}+a\right)
\end{aligned}
$$

gdzie: $K_{w b}$ - nakłady inwestycyjne przeznaczone na wbijanie ścianek szczelnych zabezpieczających wykop w trakcie budowy zbiornika rurowego, zł; $K_{w y}$ - nakłady inwestycyjne przeznaczone na usuwanie ścianek szczelnych zabezpieczających wykop w trakcie budowy zbiornika rurowego, zł; $C_{w b}$ - cena jednostkowa wbijania ścianek szczelnych w grunt, zł/m; $C_{w y}$ - cena jednostkowa usuwania ścianek szczelnych z gruntu, z $\mathrm{z} / \mathrm{m}$; $H_{o d p}$ - zagłębienie kanału odpływowego ze zbiornika, m; $D_{\text {odp }}$ - średnica kanału odpływowego ze zbiornika, m; $G_{\text {pias }}$ - grubość warstwy podsypki piaskowej pod dnem zbiornika retencyjnego, m;

$a$ - naddatek określający głębokość wbicia ścianek szczelnych poniżej warstwy podsypki piaskowej pod dnem zbiornika retencyjnego, $\mathrm{m}$.

W modelu kosztowym zbiornika rurowego wzięto również pod uwagę nakłady inwestycyjne $K_{w d}$ wynikające z wydobycia gruntu i jego transportu w trakcie wykonywania wykopów. Wartość $K_{w d}$ zależy od wymiarów koniecznych do wykonania wykopów i sposobu realizacji robót. Cena jednostkowa wydobycia gruntu $C_{w d}$ obejmuje pracę ludzi i sprzętu, m.in. koparek i samochodów transportujących urobek na składowisko gruntu na placu budowy lub poza jej teren. W analizowanym zbiorniku retencyjnym nakłady inwestycyjne $K_{w d}$ mogą zostać wyznaczone z zależności (10).

$$
K_{w d}=C_{w d} \cdot(D+2 s) \cdot(L+2 s) \cdot\left(H_{o d p}+D_{o d p}+G_{p i a s}\right)
$$

gdzie: $K_{w d W}$ - nakłady inwestycyjne przeznaczone na wydobycie gruntu i jego transport w trakcie budowy zbiornika rurowego, zł; $C_{w d}-$ cena jednostkowa wydobycia grunt, $\mathrm{z} \mathrm{k} / \mathrm{m}^{3}$. 
Zbiornik rurowy musi być posadowiony na warstwie odpowiednio zagęszczonego piasku. Dlatego też w modelu kosztowym uwzględniono nakłady inwestycyjnych obejmujące wykonanie podsypki $K_{\text {pias }}$ pod dnem zbiornika, które zależą od długości i średnicy zbiornika rurowego, grubości warstwy piasku i jego ceny. Nakłady te można obliczyć na podstawie równania (11).

$$
K_{\text {pias }}=C_{\text {pias }} \cdot(D+2 s) \cdot L \cdot G_{\text {pias }}
$$

gdzie $C_{\text {pias }}$ jest ceną jednostkową piasku w zł $/ \mathrm{m}^{3}$.

Jednym z etapów robót ziemnych jest również zasypanie wykopów po wykonaniu zbiornika. Koszt $K_{z a s}$ związany z realizacją tych prac obejmuje koszt dowozu ziemi i jej mechanicznego zagęszczenia oraz plantowania terenu po zakończeniu robót budowlanych. Dla rozpatrywanego zbiornika retencyjnego został on wyznaczony z zależności (12), jako różnica w objętości wykopów przed posadowieniem w nich rurowej konstrukcji zbiornika i po jej wykonaniu.

$$
\begin{aligned}
& K_{\text {zas }}=C_{\text {zas }} \cdot\left[(D+2 s) \cdot(L+2 s) \cdot\left(H_{\text {odp }}+D_{\text {odp }}+G_{\text {pias }}\right)-\right. \\
& +\left(L \cdot \frac{\pi D^{2}}{4}+L \cdot(D+2 s) \cdot G_{\text {pias }}\right]
\end{aligned}
$$

gdzie: $C_{z a s}$ - cena jednostkowa zasypania wykopów, zł/m³ .

Biorąc pod uwagę wszystkie opisane składowe nakładów inwestycyjnych $K_{r z}$ związanych z realizacją robót ziemnych w trakcie budowy zbiornika rurowego, całkowite nakłady $K_{r z}$ zapisano w postaci zależności (13).

$$
\begin{aligned}
& K_{r z}=C_{o d w} \cdot I_{g o d z}+\left[C_{w b} \cdot 2(D+2 s)+2(L+2 s) \cdot\left(H_{o d p}+D_{o d p}+G_{p i a s}+a\right)\right]+ \\
& +C_{w y} \cdot 2(D+2 s)+2(L+2 s) \cdot\left(H_{o d p}+D_{o d p}+G_{p i a s}+a\right)+ \\
& +C_{w d} \cdot(D+2 s) \cdot(L+2 s) \cdot\left(H_{o d p}+D_{o d p}+G_{p i a s}\right)+C_{p i a s} \cdot(D+2 s) \cdot L \cdot G_{p i a s}+ \\
& +C_{z a s} \cdot\left[(D+2 s) \cdot(L+2 s) \cdot\left(H_{o d p}+D_{o d p}+G_{p i a s}\right)-\right. \\
& \left.+\left(L \cdot \frac{\pi D^{2}}{4}+L \cdot(D+2 s) \cdot G_{p i a s}\right)\right]
\end{aligned}
$$

Kanalizacyjne zbiorniki retencyjne projektowane są najczęściej jako obiekty prostopadłościenne wykonane $\mathrm{z}$ betonu i stali, co wymaga uwzględniania w nakładach inwestycyjnych kosztów związanych z budową żelbetowej konstrukcji zbiornika. W przypadku zbiorników zbudowanych $\mathrm{z}$ odcinków rur o znacznych średnicach w całkowitych nakładach inwestycyjnych należy uwzględnić koszt zakupu, transportu i montażu zbiornika oraz jego dodatko- 
wych elementów, takich jak studzienki rewizyjne i połączeniowe. Rurowe zbiorniki retencyjne oferowane przez ich producentów zazwyczaj są już wyposażone w kominy rewizyjne, które mogą również pełnić funkcję studzienek włazowych. W takich rozwiązaniach dodatkowe studzienki mogą być instalowane lub nie, w zależności od lokalnych uwarunkowań inwestycyjnych. W nakładach przeznaczonych na wykonanie konstrukcji analizowanego zbiornika oddzielnie zostały uwzględnione nakłady wynikające $\mathrm{z}$ ilości użytych materiałów oraz koszty robocizny, które zostały przeliczone na 1 metr bieżący długości zbiornika. Zatem, ogólnie nakłady można zapisać wzorem (14).

$$
K_{k}=C_{m z} \cdot L+C_{r z} \cdot L+C_{s t} \cdot I_{s t}
$$

gdzie: $K_{k}$ - nakłady inwestycyjne przeznaczone na wykonanie konstrukcji zbiornika rurowego, zł;

$C_{m z}$ - cena jednostkowa zakupu zbiornika rurowego, zł/mb.;

$C_{r z}-$ cena jednostkowa robocizny przy wykonaniu konstrukcji zbiornika, $\mathrm{zz} / \mathrm{mb}$;

$C_{s t}$ - cena jednostkowa zakupu studzienki kanalizacyjnej, zł/szt.;

$I_{s t}$ - liczba studzienek, szt.

W zależności od wymagań inwestorów, lokalizacji zbiornika w systemie kanalizacyjnym i warunków hydraulicznych sieci zbiornik rurowy może być także wyposażony w dodatkowe elementy, takie jak: trójniki, przyłącza, regulatory przepływu, klapy oraz urządzenia płuczące. Nakłady inwestycyjne wynikające $\mathrm{z}$ dodatkowego wyposażenia zbiornika retencyjnego $K_{w}$ można zapisać ogólnie zależnością (15), natomiast szczegółowo wzorem (16). Wartość poszczególnych nakładów zależy od liczby zastosowanych w zbiorniku retencyjnym urządzeń.

$$
K_{w}=K_{k l}+K_{\text {reg }}+K_{\text {urzpt }}
$$

gdzie: $K_{k l}$ - nakłady inwestycyjne przeznaczone na zakup i montaż zwrotnych zaworów klapowych w zbiorniku retencyjnym, zł;

$K_{\text {reg }}$ - nakłady inwestycyjne przeznaczone na zakup i montaż regulatorów przepływu w zbiorniku retencyjnym, zł;

$K_{\text {urzpt }}$ - nakłady inwestycyjne przeznaczone na zakup i montaż urządzeń płuczących w zbiorniku retencyjnym, zł.

$K_{w}=C_{k l} \cdot I_{k l}+C_{\text {reg }} \cdot I_{\text {reg }}+C_{\text {urzpt }} \cdot I_{\text {urzpt }}$

gdzie: $C_{k l}$ - cena jednostkowa zwrotnych zaworów klapowych zainstalowanych w zbiorniku retencyjnym, zt/szt.;

$I_{k l}$ - liczba zwrotnych zaworów klapowych zainstalowanych w zbiorniku retencyjnym, szt.; 
$C_{\text {reg }}$ - cena jednostkowa regulatorów przepływu zainstalowanych w zbiorniku retencyjnym, zł/szt.;

$I_{\text {reg }}$ - liczba regulatorów przepływu zainstalowanych w zbiorniku retencyjnym, szt.;

$C_{\text {urzpt }}$ - cena jednostkowa urządzenia płuczącego zainstalowanego w zbiorniku retencyjnym, zł/szt.;

$I_{u r z p t}$ - liczba urządzeń płuczących zainstalowanych w zbiorniku retencyjnym, szt.

Koszt budowy sieci zlokalizowanej poniżej zbiornika zależy od jego parametrów projektowych i może znacząco wpływać na całkowite koszty $L C C$ zbiornika. Wartość tych nakładów zależy przede wszystkim od długości sieci i średnicy kanałów. Nakłady inwestycyjne $K_{s}$ dotyczące budowy sieci obejmują koszty zakupu materiałów i koszty związane z jej wykonaniem. Zatem, w zależności od liczby $n$ głównych odcinków przewodów na trasie sieci kanalizacyjnej od zbiornika do oczyszczalni ścieków nakłady inwestycyjne $K_{s}$ można ogólnie zapisać wzorem (17).

$$
\begin{aligned}
& K_{s}=C_{p r z o d p} \cdot L_{p r z o d p}+C_{\text {wprzodp }} \cdot L_{\text {przodp }} \cdot D_{\text {przodp }} \cdot\left(H_{\text {przodp }} \cdot D_{\text {przodp }}\right)+ \\
& +\sum_{i=1}^{n}\left[C_{p r z i} \cdot L_{p r z i}+C_{w p r z i} \cdot L_{p r z i} \cdot D_{p r z i} \cdot\left(H_{p r z i}+D_{p r z i}\right)\right]
\end{aligned}
$$

gdzie: $C_{\text {przodp }}$ - cena jednostkowa zakupu odcinka przewodu odpływowego ze zbiornika, zł/mb.;

$L_{\text {przodp }}$ - długość odcinka przewodu odpływowego ze zbiornika, m;

$C_{w p r z o d p}$-cena jednostkowa wykonania wykopu i ułożenia odcinka przewodu odpływowego ze zbiornika, $\mathrm{z} / \mathrm{m}^{3}$;

$D_{\text {przodp }}$ - średnica odcinka przewodu odpływowego ze zbiornika, m;

$H_{\text {przodp }}$ - zagłębienie odcinka przewodu odpływowego ze zbiornika, m;

$C_{p r z i}$ - cena jednostkowa zakupu $i$-tego odcinka przewodu sieci kanalizacyjnej zlokalizowanej poniżej zbiornika, zł/mb.;

$L_{p r z i}$ - długość i-tego odcinka przewodu sieci kanalizacyjnej zlokalizowanej poniżej zbiornika, $\mathrm{m}$;

$C_{w p r z i}$-cena jednostkowa wykonania wykopu i ułożenia $i$-tego odcinka przewodu sieci kanalizacyjnej zlokalizowanej poniżej zbiornika, $\mathrm{z} / \mathrm{m}^{3}$;

$D_{\text {przi }}$ - średnica $i$-tego odcinka przewodu sieci kanalizacyjnej zlokalizowanej poniżej zbiornika, m;

$H_{p r z i}$ - zagłębienie $i$-tego odcinka przewodu sieci kanalizacyjnej zlokalizowanej poniżej zbiornika, $\mathrm{m}$.

W kosztach eksploatacyjnych związanych z funkcjonowaniem zbiornika rurowego w systemie kanalizacyjnym powinny zostać uwzględnione głównie 
koszty czyszczenia zbiornika z osadów $K_{c z}$ oraz koszty obsługi $K_{o b}$. W przypad$\mathrm{ku}$, gdy $\mathrm{w}$ zbiorniku zostaną zainstalowane urządzenia samoczynnie płuczące, które nie wymagają zasilania z zewnątrz, to wówczas koszty $K_{c z}$ mogą zostać pominięte i jedynie $\mathrm{w}$ nakładach inwestycyjnych należałoby uwzględnić koszty ich zakupu. Najczęściej nakład pracy związany z obsługą zbiornika jest częścią obowiązków pracowników przedsiębiorstwa zarządzającego siecią kanalizacyjną, na której zlokalizowany jest zbiornik retencyjny. W takiej sytuacji można również pominąć koszty $K_{o}$.

Jeżeli zbiornik retencyjny nie zostałyby wyposażony w urządzenia samoczynnie płuczące, to $\mathrm{w}$ kosztach eksploatacyjnych należy jeszcze uwzględnić koszt czyszczenia komór $K_{c z}$, który można obliczyć z zależności (18).

$$
K_{c z}=C_{c z} \cdot L
$$

gdzie $C_{c z}$ oznacza cenę jednostkową usunięcia osadów z dna zbiornika rurowego $\mathrm{w} \mathrm{zł} / \mathrm{mb}$.

W związku z tym, że koszty eksploatacyjne ponoszone są w całym okresie funkcjonowania obiektu, to w celu uzyskania bieżącej wartości przyszłych kosztów należy je zdyskontować. Biorąc to pod uwagę, koszty te dla zbiornika rurowego można zapisać formułą (19).

$$
K_{E}=\sum_{t=1}^{T} C_{c z} \cdot L \frac{1}{(1+r)^{t}}
$$

Uwzględniając wszystkie omówione składowe początkowych nakładów inwestycyjnych oraz kosztów eksploatacyjnych, całościowy model kosztowy $L C C$ zbiornika rurowego przyjmie postać zależności (20).

$$
\begin{aligned}
& K_{r z}=C_{\text {ziem }} \cdot(L+2 s) \cdot(D+2 s)+C_{o d w} \cdot I_{\text {godz }}+ \\
& +C_{w b} \cdot 2(D+2 s)+2(L+2 s) \cdot\left(H_{\text {odp }}+D_{\text {odp }}+G_{\text {pias }}+a\right)+ \\
& +C_{w y} \cdot 2(D+2 s)+2(L+2 s) \cdot\left(H_{o d p}+D_{o d p}+G_{p i a s}+a\right)+ \\
& +C_{w d} \cdot(D+2 s) \cdot(L+2 s) \cdot\left(H_{o d p}+D_{o d p}+G_{\text {pias }}\right)+C_{\text {pias }} \cdot(D+2 s) \cdot L \cdot G_{\text {pias }}+ \\
& +C_{\text {zas }} \cdot\left[(D+2 s) \cdot(L+2 s) \cdot\left(H_{\text {odp }}+D_{\text {odp }}+G_{\text {pias }}\right)-\right. \\
& \left.+\left(L \cdot \frac{\pi D^{2}}{4}+L \cdot(D+2 s) \cdot G_{p i a s}\right)\right]+C_{m z} \cdot L+C_{r z} \cdot L+C_{s t} \cdot I_{s t}+ \\
& +C_{k l} \cdot I_{k l}+C_{\text {reg }} \cdot I_{\text {reg }}+C_{\text {urppt }} \cdot I_{\text {urppt }}+ \\
& +C_{\text {przodp }} \cdot L_{\text {przodp }}+C_{\text {wprzodp }} \cdot L_{\text {przodp }} \cdot D_{\text {przodp }} \cdot\left(H_{\text {odp }} \cdot D_{\text {przodp }}\right)+ \\
& +\sum_{i=1}^{n}\left[C_{p r z i} \cdot L_{p r z i}+C_{w p r z i} \cdot D_{p r z i} \cdot\left(H_{p r z i}+D_{p r z i}\right)\right]+\sum_{t=1}^{T} C_{c z} \cdot L \frac{1}{(1+r)^{t}}
\end{aligned}
$$




\section{Podsumowanie}

Problem regulowania odprowadzania ścieków deszczowych ze zlewni miejskich jest ciągle ważny i aktualny. Jednym z jego rozwiązań jest stosowanie obiektów retencyjnych, które umożliwiają odciążenie hydrauliczne sieci i oczyszczalni ścieków poprzez czasowe magazynowanie spływających ścieków deszczowych. Istnieje wiele rozwiązań układów hydraulicznych zbiorników retencyjnych, co często stwarza problemy projektantom przy wyborze najkorzystniejszego ich wariantu. Najczęściej jedynym kryterium wyboru są nakłady inwestycyjne przeznaczone na budowę zbiornika retencyjnego. Jednak jak pokazują, niektóre przypadki zastosowanie tylko tego kryterium może prowadzić do podjęcia błędnych decyzji, z punktu widzenia finansowego. Rozwiązanie, które charakteryzuje się niskimi nakładami finansowymi może w całym okresie jego funkcjonowania generować bardzo wysokie koszty eksploatacyjne. W związku z tym opracowano model optymalizacyjny jednego z konstrukcji zbiorników retencyjnych, w którym kryterium wyboru stanowiło minimum kosztów Life Cycle Cost.

W artykule przedstawiono model kosztowy budowy i funkcjonowania zbiornika rurowego w systemie kanalizacyjnym, który w kolejnym etapie badań zostanie przekształcony w model optymalizacyjny. Zastosowana metodologia Life Cycle Cost umożliwiła uwzględnienie początkowych nakładów inwestycyjnych ponoszonych w roku zerowym oraz kosztów eksploatacyjnych w całym okresie współdziałania zbiornika z siecią.

\section{Literatura}

[1] Bakis N., Kagiouglou M., Aouad G., Amaratunga D., Kishk M. i Al-Hajj A.: An Integrated Environment for Life Cycle Costing in Construction, 2003.

[2] Czarniecki D., Słyś D.: Analiza techniczna i finansowa wariantów ogrzewania wody z wykorzystaniem pomp ciepła współpracujących z systemami rozsączania wody deszczowej w produkcji roślinnej, Czasopismo Inżynierii Lądowej, Środowiska i Architektury, Oficyna Wydawnicza Politechniki Rzeszowskiej, t. 3, s. 33-51, Rzeszów 2014.

[3] Dziaduch I.: Analiza kosztów okresu istnienia (LCC) obiektu technicznego w aspekcie jego niezawodności. Logistyka, nr 2, 2011.

[4] Dziopak J.: Modelowanie wielokomorowych zbiorników retencyjnych w kanalizacji. Oficyna Wydawnicza Politechniki Rzeszowskiej, Rzeszów 2004.

[5] Dziopak J., Słyś D.: Modelowanie zbiorników klasycznych i grawitacyjnopompowych w kanalizacji. Oficyna Wydawnicza Politechniki Rzeszowskiej, Rzeszów 2007.

[6] Dziopak J., Stec A., Słyś D.: Rurowy zbiornik retencyjny. Patent nr 216617. Urząd Patentowy RP. 
[7] Dyrektywa 2000/60/WE Parlamentu Europejskiego i Rady z dnia 23 października 2000 roku ustanawiająca ramy wspólnotowego działania w dziedzinie polityki wodnej.

[8] Epstein M.: Measuring Corporate Environmental Performance, McGraw-Hill, Chicago, IL 1996.

[9] Geiger W., Dreiseitl H.: Nowe sposoby odprowadzania wód deszczowych. Oficyna Wydawnicza Projprzem EKO, Bydgoszcz, 1999.

[10] Gluch P., Baumann H.: The life cycle costing (LCC) approach: a conceptual discussion of its usefulness for environmental decision-making. Building and Environment, Vol. 39, 2004.

[11] Holzhüter E.: Główne czynniki kształtujące koszty eksploatacji LCC układów pompowych. Pompy i Pompownie, nr. 11, 2000.

[12] Hong T., Han S., Lee S.: Simulation-based determination of optimal life-cycle cost for FRP bridge deck panels. Automation and Constructions, no. 16, 2007.

[13] Jędral W.: Dobór optymalnych parametrów oraz wybór pomp sieciowych w źródłach ciepła na podstawie kosztu życia LCC. Ciepłownictwo, Ogrzewnictwo, Wentylacja, nr 10, 2010.

[14] Karmowski Z., Rynkowski P.: Analiza techniczno-ekonomiczna wykorzystania pomp ciepła na przykładzie wybranego obiektu. Budownictwo i Inżynieria Środowiska, nr 1, 2010.

[15] Kaźmierczak B., Kotowski A.: The influence of precipitation intensity growth on the urban drainage systems designing, Theoretical and Applied Climatology, 118, 2014, s. 285-296.

[16] Materiały graficzne firmy Uponor Infra.

[17] Pochwat K., Słyś D.: Innowacyjny wysokosprawny zbiornik retencyjny wód deszczowych, Magazyn Autostrady, nr 1-2, 2016, s. 38-40.

[18] Słyś D.: Zrównoważone systemy odwodnienia miast. Dolnośląskie Wydawnictwo Edukacyjne, Wrocław 2013.

[19] Słyś D., Dziopak J.: Retencyjny kanał ściekowy. Patent nr 217405. Urząd Patentowy RP.

[20] Słyś D., Stec A.: Analiza LCC wariantów zagospodarowania wód deszczowych w budynku wielorodzinnym. Proceedings of ECOpole, Vol. 6, No. 1, 2012.

[21] Słyś D., Stec A., Zelenakova M.: A LCC analysis of rainwater management variants. Ecological Chemistry and Engineering S, Vol. 19, No. 3, 2012.

[22] Stec A.: Optymalizacja innowacyjnych zbiorników w kanalizacji ogólnospławnej. Rozprawa doktorska. Akademia Górniczo-Hutnicza w Krakowie, Kraków 2013.

[23] Stec A.: Optimization of the hydraulic system of the storage reservoir hydraulically unloading the sewage network. Ecological Chemistry and Engineering S, Vol. 21, No. 2, 2014, s. 215-228.

[24] Suligowski Z.: Redukcja spływu wód opadowych. Wodociągi i Kanalizacja, nr 6/2007.

[25] Suligowski Z.: Alternatywa dla wód opadowych. Wodociągi i Kanalizacja, nr 4/2008. 
[26] Świderski M.: Analiza LCC (Life Cycle Cost Analysis) narzędziem wspomagającym ocenę projektów inwestycyjnych związanych z techniką pompową. IX Forum Użytkowników Pomp, Szczyrk 2003.

[27] Ulatowski W.: Analiza kosztów urządzeń infrastruktury tramwajowej w pełnym cyklu życia. Technika Transportu Szynowego, nr 9, 2007.

[28] White G., Ostwald P.: Life cycle costing. Management Accounting, January 1976.

[29] Woodward D., Demirag I.: Life cycle costing. Career Accountant, November 1989.

\section{COST MODEL OF THE PIPE STORAGE RESERVOIR}

\section{S u m m a r y}

In this article the issues related to sewage retention in pipe tanks were described and the formulated cost model of this tank was presented, which in the next stage of the research will be transformed into an optimization model and then implemented in a programming language AMPL (A Mathematical Programming Language). The cost model was prepared with an application of Life Cycle Cost methodology, which allows to determine the cost of the whole life cycle of the object. In this model the initial investment costs related to the construction of this tank and operation costs were taken into account.

Life Cycle Cost methodology allows to make the right decision, from the point of view of the investor. The capital expenditure included expenses for the purchase of land for investments, expenditure for the implementation of earthworks related to the construction of a storage reservoir, expenditure including the execution of tubular construction and expenses for the construction of the sewage network located below the storage reservoir. Therefore, it is a gravity tank which allow to avoid the costs resulting from the pumping of wastewater, and in annual operating costs only the cost of sludge removal were taken into account. Due to the fact that sewage systems and objects cooperating with them are designed for a very long period of time, in the developed cost model the costs of decommissioning the tank was not considered.

Keywords: pipe tanks, sewage reservoirs, Life Cycle Cost, optimization

DOI: $10.7862 /$ rb.2016.176

Przestano do redakcji: 01.05.2016 $r$.

Przyjęto do druku: 28.06.2016 r. 